5 Kaplan M, Kauli R, Raviv V, Lubin E, Laron Z. Hypothyroidism due to ectopy in siblings. Am $J$ Dis Child $1977 ; 131$ : 1264-5.

- Montgomery $\mathbf{M}$ L. Lingual thyroid. Comprehensive review. Western J Surg 1936; 44: 54-60.

7 Little G, Meador C K, Cunningham R, Pittman J A. 'Cryptothyroidism' the major cause of sporadic 'athyreotic' cretinism. J Clin Endocrinol Metab 1965; 25: 1529-36.

8 Lahey F H. Lingual goiter. Surg Gynecol Obstet 1923; 36 : 395-7.
9 Jain S N. Lingual thyroid. Int Surg 1969; 52: 320-5.

10 McGirr E M, Hutchison J H. Dysgenesis of the thyroid gland as the cause of cretinism and juvenile myxoedema. J Clin Endocrinol Metab 1955; 15: 668-79.

11 Hutchison J H. In: Mason A S, ed. The thyroid and its diseases. Philadelphia: Lippincott, 1963: 39-60.

Correspondence to Professor Y Gilboa, The Endocrine Service, Assaf Harofeh Hospital, Zerifin 70 300, Israel.

\title{
Control of life-threatening bleeding by combined plasmapheresis and immunosuppressive treatment in a haemophiliac with inhibitors
}

\author{
T RÉVÉSZ, J MÁTYUS, B GOLDSCHMIDT, AND VERONIKA HARSANYI \\ 2nd Department of Paediatrics, Semmelweis University of Medicine, and \\ National Institute of Haematology and Blood Transfusion, Budapest, Hungary
}

SUMMARY Life-threatening lingual haemorrhage was successfully treated in a 3-year-old haemophiliac who had a high level of inhibitor in his plasma. Repeated plasma exchange with high-dose factor VIII concentrate led to a cessation of bleeding. Immunosuppressive treatment introduced at the time of plasmapheresis and carried out for 6 weeks seems to have prevented the return of the inhibitor.

The presence of inhibitors in patients with severe haemophilia A presents a serious clinical problem. Patients who had previously been well managed on 'average' replacement therapy, fail to respond to large doses of factor VIII concentrates. About 10\% of haemophiliacs eventually develop inhibitors although the time they take to do so varies. ${ }^{1}$ Attempts at overcoming this problem started soon after it became recognised. Approaches have been found to be beneficial by some and ineffective by others. The use of high-dose factor VIII concentrates with concomitant immunosuppression was advocated by Nilsson and Hedner. ${ }^{2}$ Several authors have reported success with the use of activated or nonactivated prothrombin complex concentrates. ${ }^{3}$ Others have failed to confirm these findings, and furthermore have warned of the possibility of severe untoward effects-such as disseminated intravascular coagulation-after the use of such compounds. ${ }^{4}$

Plasmapheresis as a prompt measure for the control of severe bleeding has been successfully tried at a number of centres for haemophiliacs. ${ }^{5-6}$ In some of these patients plasmapheresis was followed by short-term immunosuppressive treatment. In most patients however, the inhibitor level returned to pre- treatment values within days or weeks of plasmapheresis. Continuous flow plasmapheresis has been suggested for adult patients but these instruments are expensive and somewhat difficult to use with small children.

We report a case of haemophilia A with inhibitors in a 3-year-old boy, who had repeated lifethreatening bleeding from his tongue. Bleeding was successfully controlled by 'conventional' plasma exchange with factor VIII concentrate and fresh frozen plasma. Immunosuppression, introduced at the time of plasmapheresis, seems to have led to the disappearance of the factor VIII inhibitor.

\section{Case report}

There was no history of haemophilia in the family of our patient nor was there history of any other bleeding disorder. Our patient's mother subsequently was found to be an asymptomatic carrier for haemophilia A. The patient was first investigated for suspected haemorrhagic disorder when he had prolonged bleeding after a diphtheria-pertussistetanus vaccination. The diagnosis of haemophilia A was established at age 4 months. Factor VIII level was found to be less than $1 \%$. He repeatedly received cryoprecipitate and transfusions for gum and nose bleeds. 10-20 units per $\mathrm{kg}$ factor VIII were then adequate for the control of bleeding. Altogether he was treated on 33 occasions before the age of 2 years. At 25 months gingival haemorrhage started and this time it did not respond to 'conventional' treatment. A factor VIII inhibitor was detected in his plasma with a concentration of 10 Bethesda units per $\mathrm{ml}$. The bleeding was eventually controlled by 
Table Coagulation studies and treatment of haemorrhages in patient

\begin{tabular}{|c|c|c|c|c|c|c|c|}
\hline & \multicolumn{7}{|c|}{ Age (months) } \\
\hline & 22 & 25 & 26 & 31 & 33 & $33 \cdot 5$ & 37 \\
\hline $\begin{array}{l}\text { Coagulation } \\
\text { Bleeding } \\
\text { Haemoglobin (g/dl) (lowest, before transfusion) } \\
\text { Partial thromboplastin time (seconds) } \\
\text { Factor VIII level (\%) } \\
\text { Factor VIII inhibitor (Bethesda units) }\end{array}$ & $\begin{array}{l}\text { Inguinal } \\
6 \cdot 3 \\
>180 \\
<1 \\
0\end{array}$ & $\begin{array}{l}\text { Gingival, nose, joints } \\
7 \cdot 2 \\
170 \\
<1 \\
10\end{array}$ & $\begin{array}{l}\overline{9 \cdot 5} \\
>120 \\
<1 \\
14\end{array}$ & $\begin{array}{l}\text { Tongue } \\
4 \cdot 4 \\
>120 \\
<1 \\
8\end{array}$ & $\begin{array}{l}\text { Tongue } \\
4 \cdot 8 \\
>120 \\
<1 \\
8\end{array}$ & $\begin{array}{l}\text { Tongue } \\
5 \cdot 9 \\
>120 \\
<1 \\
8\end{array}$ & $\begin{array}{l}\overline{12} \cdot 1 \\
70 \\
<1\end{array}$ \\
\hline $\begin{array}{l}\text { Treatment } \\
\text { Blood transfusion (ml) total } \\
\text { Factor VIII concentrate } \\
\text { FEIBA } \\
\text { Fresh frozen plasma } \\
\text { Plasmapheresis (ml) } \\
\text { Prednisolone } \\
\text { Cyclophosphamide }\end{array}$ & $\begin{array}{r}800 \\
4200 \\
250\end{array}$ & $\begin{array}{l}1720 \\
7000\end{array}$ & & $\begin{array}{r}2760 \\
11800 \\
12000\end{array}$ & $\begin{array}{r}3760 \\
10600 \\
100 \\
2 \times 600 \\
25 \mathrm{mg} \\
50 \mathrm{mg}\end{array}$ & $\begin{array}{r}1260 \\
10000 \\
600 \\
1000 \\
25 \mathrm{mg} \\
50 \mathrm{mg}\end{array}$ & \\
\hline
\end{tabular}

7000 units factor VIII in cryoprecipitate. There was a transient rise in the inhibitor level after replacement therapy (Table).

Six months later severe bleeding started from his tongue. Large doses of activated prothrombin complex concentrate (FEIBA, Immuno Ag, Vienna) were tried without success to control the bleeding. Haemorrhage continued despite the simultaneous use of FEIBA and cryoprecipitate given in a total dose of 12000 and 1800 units respectively, over a period of 5 days. Finally 'intensive' factor VIII treatment, using 1000 units Cryobulin (Immuno Ag, Vienna) every 8 hours for 3 days brought the haemorrhage under control. The child then spent 8 weeks at home; during this time he was symptomfree. He then bit his tongue again and was admitted to hospital with severe blood loss. The presence of high-titre inhibitor and the difficulty in achieving haemostatic factor VIII level prompted us to carry out plasma exchange. The procedure was as follows: after cannulation of the left saphenous vein, plasmapheresis was performed with disposable bloodcollecting bags. The bags were centrifuged at 3000 $\mathrm{rev} / \mathrm{min}$ for 10 minutes in a Sorvall RC-3 centrifuge. Plasmapheresis was accomplished on 2 consecutive days. Each day $600 \mathrm{ml}$ of blood were plasmapheresed giving about $340 \mathrm{ml}$ of plasma. The exchange was carried out in 100-150 ml aliquots to avoid problems with the volume. Although transient tachycardia and tachypnoea were observed, these were easily controlled by transfusion with donor blood. The patient's own erythrocytes were transfused back with $100 \mathrm{ml}$ fresh frozen plasma and $200 \mathrm{ml}$ cryoprecipitate (factor VIII concentration: 600 units). After the plasmapheresis, cyclophosphamide was given in an initial dose of $150 \mathrm{mg}$ intravenously, followed by a 'maintenance' dose of $50 \mathrm{mg}(3.6 \mathrm{mg}$ per $\mathrm{kg}$ ) daily, with $25 \mathrm{mg}$ prednisolone $(2 \mathrm{mg}$ per $\mathrm{kg}$ ) (Figure).

The bleeding from the patient's tongue stopped

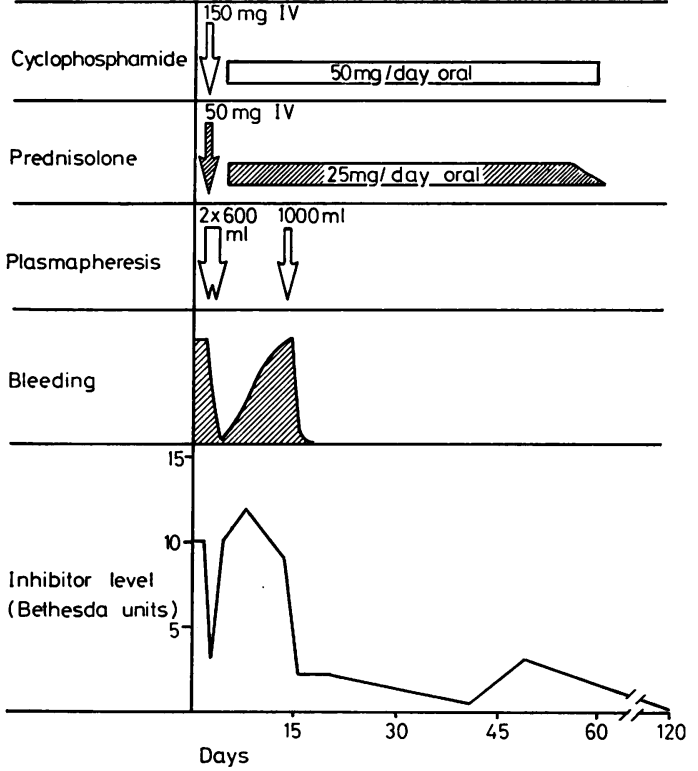

Figure Effect of combined plasmapheresis and immunosuppressive treatment on factor VIII inhibitor activity.

during the second day of plasmapheresis, but oozing started again 4 days later. High-dose factor VIII treatment (total 10000 units) this time failed to control the haemorrhage, and the patient's condition quickly deteriorated.

A second course of plasmapheresis was carried out 2 weeks later and a total of $1000 \mathrm{ml}$ blood was plasmapheresed in one day. The discarded plasma $(650 \mathrm{ml})$ was substituted for fresh frozen plasma, and 10000 units of factor VIII (Cryobulin) given in an initial dose of 1000 units every 8 hours. Anaemia due to blood loss also necessitated red cell replacement. The lingual haemorrhage promptly stopped 
during plasmapheresis. Immunosuppressive treatment was carried out for a period of 6 weeks.

The level of factor VIII inhibitor was measured using the method of Kasper et al. ${ }^{7}$ Three, 4, and 10 months after the second plasmapheresis, there was no detectable inhibitor in the patient's serum (Figure).

\section{Discussion}

Plasma exchange with fresh frozen plasma and factor VIII concentrates led to the lingual haemorrhage stopping in our patient, who had a high level of factor VIII inhibitor in his plasma. Serial analysis of the inhibitor level showed that it dropped from 10 to 3 Bethesda units after the first 2 days of plasmapheresis. Two days later however, it had returned to preplasmapheretic values, and it even rose to 12 units, corresponding probably to a rebound from the tissue pools. It was not surprising that bleeding started again a few days later, reaching a lifethreatening rate in 10 days. After the second course of plasma exchange, bleeding stopped, and the level of the inhibitor fell to 2 units. Probably as a result of immunosuppressive treatment introduced at the time of the first plasmapheresis, the inhibitor level has remained low ever since. 10 months after plasmapheresis, the inhibitor level was nil, and the patient was symptom-free.

Plasmapheresis can lead to a rapid improvement of the clinical state in severe haemophilia with inhibitors. The secondary rise in the inhibitor level can most probably be avoided by more-prolonged intensive plasma exchange or by the simultaneous use of immunosuppressive treatment. Furthermore, as seems to be the case so far in our patient, the inhibitor may even disappear completely. Although the disappearance might have occurred spontaneously there is reason to believe that it was connected with the therapeutic procedure; however it is not possible at present to give a sound explanation. We recommend therefore a combination of plasmapheresis with simultaneous intensive immunosuppression.

\section{References}

1 Josso F, Cosson A, Gazengel C, Allain J P. Inhibitors in haemophilia. In: Ala F, Denson K W E, eds. Haemophilia. Amsterdam: Excerpta Medica, 1973: 260-9.

2 Nilsson I M, Hedner U. Immunosuppressive treatment in haemophiliacs with inhibitors to factor VIII and factor IX. Scand J Haematol 1976; 16: 369-74.

3 Allain J P, Krieger G R. Letter: Prothrombin-complex concentrate in treatment of classical haemophilia with factor-VIII antibody. Lancet 1975; ii: 1203.

4 Stenbjerg S, Jørgensen J. Letter: Disseminated intravascular coagulation and infusion of factor VIII inhibitor bypassing activity. Lancet 1977; i: 360 .

5 Capitanio A, Coppola R, Manucci P M, Ruggeri Z M. Replacement therapy for haemophiliacs with factor VIII inhibitors. In: Ulutin O N, Peake J R, eds. Haemophilia. Excerpta Medica International Congress Series No 356. Amsterdam: Excerpta Medica, 1975: 213-20.

- Piller G, Höcker P, Ludwig E, Niessner H, Rainer H, Lechner K. Plasmapheresis: its role in the management of inhibitor patients. In: Deutsch E, Lechner K, Eibl $\mathbf{H}$, eds. Workshop on inhibitors of factors VIII and IX. Wien: Facultas Verlag, 1977: 57-64.

7 Kasper C K, Aledort L M, Counts R B, et al. Letter: A more uniform measurement of factor VIII inhibitors. Thromb Diathes Haemorrhag 1975; 34: 869-72.

Correspondence to Dr T Révész, 2nd Department of Paediatrics, Semmelweis University of Medicine, Budapest IX, Tüzoltó u. 7-9, 1094 Hungary.

\title{
Nonaccidental poisoning: the elusive diagnosis
}

\author{
JOHN LORBER, JOHN P D RECKLESS, AND J BRENDAN G WATSON \\ Department of Paediatrics, Children's Hospital, and Department of Paediatrics, Hallamshire Hospital, \\ Sheffield
}

SUMMARY Although nonaccidental poisoning in childhood is now more often recognised, it is still difficult to establish a diagnosis despite correct investigative procedures. In 1978 we were unable, initially, to establish the cause for intermittent episodes of loss of consciousness in a boy admitted to Sheffield Children's Hospital. Subsequently it was conclusively shown that his mother systematically poisoned him with Tuinal (amylobarbitone and quinalbarbitone) both before admission and while he was being treated in the hospital.
Most paediatricians are aware of the possibility of nonaccidental poisoning as part of the syndrome of child abuse, and a recent publication ${ }^{1}$ has heightened our own awareness of the possibility. Meadow ${ }^{2}$ described 2 cases which he attributed to a form of 'Munchausen's syndrome by proxy' in which the children were deliberately and systematically poisoned by their parents. Verity et al. ${ }^{3}$ reported 2 similar patients who were being persistently poisoned by their mother. The main barrier to establishing a firm diagnosis is often the ingenuity of the parents in offering plausible explanations for the child's 